\title{
PENGARUH PENETAPAN HARGA DAN BIAYA PROMOSI TERHADAP HASIL PENJUALAN SEPATU GINO MARIANI PADA PT. SEPATU MAS IDAMAN
}

\section{THE LEVERAGE OF PRICING AND PROMOTION COSTS ON THE SALE OF GINO MARIANI SHOES AT PT SEPATU MAS IDAMAN}

\author{
Fauzan Zikri ${ }^{1}$, Intan Pematasari ${ }^{2}$, Zuber $^{3}$
}

\author{
${ }^{1}$ Universitas Pradita, J1. Gading Serpong Boulevard, Tangerang, Banten 15810 \\ ${ }^{2}$ Universitas Suryakancana, J1. Pasir Gede Raya Cianjur \\ ${ }^{3}$ Universitas Suryakancana, J1. Pasir Gede Raya Cianjur \\ Email: fauzanzikri8@gmail.com
}

\begin{tabular}{|l|l|l}
\hline Masuk: 24 Mei 2021 & Penerimaan: 25 Mei 2021 & Publikasi: 28 Juni 2021
\end{tabular}

\begin{abstract}
ABSTRAK
Penelitian ini bertujuan untuk mengetahui seberapa besar pengaruh penetapan harga dan biaya promosi terhadap hasil penjualan. Adapun variabel yang diobservasi dalam penelitian ini terdiri dari tiga variabel dimana penetapan harga sebagai variabel $X_{1}$ biaya promosi sebagai variabel $X_{2}$ dan penjualan sebagai variabel Y. Di dalam penelitian ini untuk memperoleh data menggunakan data primer dan data sekunder yang tujuannya mengolah data dalam bentuk kuantitatif dan kualitatif. Adapun, Penetapan harga dan biaya promosi terhadap hasil penjualan menggunakan metode Regresi Linier Berganda, sedangkan untuk mengolah data menggunakan software SPSS versi 22.0. Berdasarkan hasil penelitian diperoleh bahwa persamaan regresi linier berganda yaitu $\hat{Y}=(19320803,412)+$ $96387,612 \mathrm{X}_{1}+588,234 \mathrm{X}_{2}$ Sedangkan, hasil regresi sederhana membuktikan bahwa pengaruh harga $\left(\mathrm{X}_{1}\right)$ terhadap hasil penjualan yaitu sebesar 0,738 dengan tingkat kontribusi yang disumbangkan variabel $\mathrm{X}_{1}$ terhadap $\mathrm{Y}$ adalah $\mathrm{KP}=(r)^{2} \times 100 \%=(0,738)^{2} \times 100 \%=54,46 \%$ dan biaya promosi $\left(\mathrm{X}_{2}\right)$ terhadap hasil penjualan yaitu sebesar 0,878 dengan tingkat kontribusi yang disumbangkan variabel $\mathrm{X}_{2}$ terhadap $\mathrm{Y}$ adalah $\mathrm{KP}=(r)^{2} \times 100 \%=(0,878)^{2} \times 100 \%=77,09 \%$. Adapun hasil kedua variabel independen dinyatakan kuat karena mendekati $(+1)$ sebesar 0,984 dan sementara yang disumbangkan

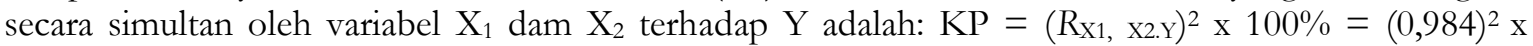
$100 \%=96,8 \%$, sedangkan, sisanya 3,2 \% ditentukan oleh variabel lain disebabkan oleh faktor-faktor lainnya seperti produksi dan distribusi terhadap hasil penjualan di PT Sepatu Mas Idaman.
\end{abstract}

Kata kunci: Penetapan Harga, Biaya Promosi, Hasil Penjualan

\begin{abstract}
This research aims to determine how much influence pricing and promotion costs have on sales results. The variables observed in this study consisted of three variables in which the pricing as variable $X_{1}$ promotion costs as variable $X_{2}$ and sales as variable $Y$. In this research to obtain data using primary data and secondary data with the purpose of processing data in the form of quantitative and qualitative. Meanwhile, pricing and promotional costs for sales results use the Multiple Linear Regression method, while data processing uses the SPSS version 22.0 program. Based on the research results, it is found that the multiple linear regression equation is $\hat{Y}=(19320803,412)+96387,612 X_{1}+588,234$ $X_{2}$ Meanwhile, the simple regression results prove that the effect of price $\left(X_{1}\right)$ on sales results is 0.738 with the level of contribution contributed by the variable $X_{1}$ to $Y$ is $K P=(r)^{2} \times 100 \%=(0.738)^{2} \times 100 \%=54.46 \%$ and promotion costs $\left(X_{2}\right)$ to sales results are 0.878 with the level of contribution that $X_{2}$ variable contributes to $Y$ is $K P=(r)^{2} x$ $100 \%=(0.878)^{2} \times 100 \%=77.09 \%$. The results of the two independent variables are stated to be strong because they are close to $(+1)$ of 0.984 and while those that are contributed simultaneously by variables $X_{1}$ and $X_{2}$ to $Y$ are: KP=
\end{abstract}


Pengaruh Penetapan Harga dan Biaya Promosi terhadap Hasil Penjualan Sepatu Gino Mariani pada

$\left(R_{X 1}, X 2 . Y\right)^{2} \times 100 \%=(0.984)^{2} \times 100 \%=96.8 \%$, meanwhile, the remaining $3.2 \%$ is determined by other variables due to other factors such as production and distribution of sales at PT Sepatu Mas Idaman.

Keywords: Pricing, Promotion Costs, Sales Results

\section{PENDAHULUAN}

Industri adalah suatu usaha pengolahan bahan baku atau barang setengah jadi menjadi barang jadi yang memiliki nilai tambah untuk mendapatkan keuntungan. Perakitan (assembling) atau reparasi merupakan segmen dari industri (Godam, 2006). Seiring dengan perkembangan pesat industri di tanah air, maka terjadi persaingan yang cukup ketat antar perusahaan. Disamping itu, industri erat kaitannya dengan perdagangan, karena perdagangan merupakan faktor penting bagi perekonomian suatu negara. Hubungan antara perdagangan dan industri merupakan sinergi dalam mendukung perekonomian dalam negeri agar dapat mempunyai daya saing yang kuat terhadap dampak krisis global. Kekuatan ekonomi dalam negeri dan tingkat partisipasi masyarakat dalam mendukung produk dalam negeri perlu diimbangi oleh kekuatan produksi nasional. Dari dua faktor penting tersebut tentu perusahaan memiliki aspek-aspek penting di dalam peningkatan suatu perusahaan diantaranya aspek pemasaran, keuangan, hukum, teknis/teknologi, manajemen \& organisasi dan aspek ekonomi serta sosial.

Namun dari keenam aspek yang ada aspek pemasaran merupakan aspek yang paling terpenting untuk kemajuan perusahaan barang/jasa dikarenakan pemasaran merupakan kunci utama dalam membangun aspek-aspek yang lainnya. Dengan demikian, dapat dikatakan bahwa kelangsungan hidup perusahaan tergantung pada kebijakan strategi pemasaran yang ditentukan oleh perusahaan tersebut. Aspek pemasaran cukup berperan dalam usaha pencapaian tujuan perusahaan.

Banyak perusahaan yang memakai keenam aspek tersebut, baik kecil, usaha menengah sampai pada usaha besar. Salah satunya adalah perusahaan sepatu dengan menggunakan banyak bahan mentah yang dimiliki negara ini, Sehingga industri sepatu menjadi pilihan yang tepat bagi perusahaan asing untuk bekerjasama dengan Indonesia. Banyak ragam sepatu yang dibuat semakin banyak inovasi yang dilakukan. Ini tentu menjadi tantangan tersendiri bagi perusahaan yang membuat sepatu. Penelitian ini dilakukan di salah satu perusahaan sepatu yang terdapat di daerah Bogor, yaitu PT. Sepatu Mas Idaman. Perusahaan ini bergerak pada bidang industri sepatu kulit. Bahan dasar pembuatan yaitu leather, outsole, insole, lining, assesories, footbed, carton.

Perusahaan tersebut telah banyak memproduksi sepatu kulit dimulai dari sepatu casual, sepatu kantoran sampai pada sepatu anak-anak. Banyaknya pembuatan yang dilakukan tentu 
Pengaruh Penetapan Harga dan Biaya Promosi terhadap Hasil Penjualan Sepatu Gino Mariani pada PT. Sepatu Mas Idaman

terdapat beberapa kendala yang saat ini dihadapi oleh PT. Sepatu Mas Idaman adalah teknologi yang digunakan merupakan alat-alat yang umur ekonomisnya sudah tua, lokasi pabrik yang kurang memadai, dampak limbah pabrik yang bisa merusak lingkungan sekitar, penjualan merek lokal yang tidak kunjung terjadinya kenaikan yang signifikan atau cenderung standar, promosi yang kurang baik. Hal ini mengakibatkan pendapatan yang didapat oleh perusahaan kadang kala hanya cukup untuk memenuhi kebutuhan operasional perusahaan.

Sesuai dengan pengamatan dan informasi dari manajemen perusahaan ada sejumlah kendala yang mungkin dapat menghambat tingkat penjualan yaitu akses jalan yang kurang baik, proses produksi bukan di kawasan industri, limbah pabrik yang mengganggu masyarakat, kurang luasnya lahan produksi, mesin produksi yang sudah tidak sebanding dengan proses produksi, proses ekspor-impor yang masih sering terlambat, keuangan terutama laporan hutang yang belum begitu baik pencatatannya dan penetapan harga yang tidak tetap serta promosi terhadap pelanggan masih kurang inovasi. Berdasarkan hasil kajian yang didapatkan dari hasil pengamatan yang menjadi masalah utama yang menghambat tingkat penjualan adalah penetapan harga sepatu Gino Mariani dan biaya promosi. Adapun, tujuan dari penelitian ini adalah untuk mengetahui pengaruh penetapan harga dan biaya promosi secara simultan terhadap hasil penjualan pada PT. Sepatu Mas Idaman.

\section{METODE PENELITIAN}

Penelitian ini dilakukan pada PT Sepatu Mas Idaman, variabel yang diamati dalam penelitian ini termasuk dari tiga variabel yaitu penetepan harga, biaya promosi dan hasil penjualan. Bila dilihat dari cara perolehan data, maka pengumpulan data dapat menggunakan data primer dan data sekunder. Penganalisaan terhadap data yang diperoleh menggunakan analisis kuantiatif dan kualitatif. Adapun, sesuai dengan tujuan penelitian ini, maka jenis dan metode penelitian yang digunakan adalah menggunakan metode regresi linier berganda sedangkan pengolahan data menggunakan SPSS (Statistical Product Service and Solution) versi 22.0.

\section{HASIL DAN PEMBAHASAN}

\section{Penjualan ( $\mathbf{Y})$}

Tabel I. Data Hasil Penjualan merk Gino Mariani tahun 2011-2013 Per Kuartal (dalam rupiah) 
Pengaruh Penetapan Harga dan Biaya Promosi terhadap Hasil Penjualan Sepatu Gino Mariani pada PT. Sepatu Mas Idaman

\begin{tabular}{|l|r|c|c|}
\hline Tahun & \multicolumn{1}{|c|}{ KUARTAL } & $\begin{array}{c}\text { Realisasi } \\
\text { Penjualan }(\mathrm{Y})\end{array}$ & $\begin{array}{c}\text { Target } \\
\text { Penjualan }\end{array}$ \\
\hline \multirow{4}{*}{2011} & I & 7.173 .932 .594 & 9.000 .000 .000 \\
\cline { 2 - 4 } & II & 10.760 .898 .892 & 11.000 .000 .000 \\
\cline { 2 - 4 } & III & 17.934 .831 .486 & 17.000 .000 .000 \\
\cline { 2 - 4 } & TOTAL & $\mathbf{3 5 . 8 6 9 . 6 6 2 . 9 7 2}$ & $\mathbf{4 0 . 0 0 0 . 0 0 0 . 0 0 0}$ \\
\cline { 2 - 4 } & I & 6.886 .438 .940 & 10.000 .000 .000 \\
\cline { 2 - 4 } & II & 10.329 .658 .409 & 15.000 .000 .000 \\
\cline { 2 - 4 } & III & 17.216 .097 .349 & 20.000 .000 .000 \\
\cline { 2 - 4 } & TOTAL & $\mathbf{3 4 . 4 3 2 . 1 9 4 . 6 9 8}$ & $\mathbf{4 5 . 0 0 0 . 0 0 0 . 0 0 0}$ \\
\cline { 2 - 4 } & I & 9.978 .032 .064 & 10.000 .000 .000 \\
\cline { 2 - 4 } & II & 14.967 .048 .096 & 15.000 .000 .000 \\
\cline { 2 - 4 } & III & 24.945 .080 .160 & 25.000 .000 .000 \\
\cline { 2 - 4 } & TOTAL & $\mathbf{4 9 . 8 9 0 . 1 6 0 . 3 2 0}$ & $\mathbf{5 5 . 0 0 0 . 0 0 0 . 0 0 0}$ \\
\hline
\end{tabular}

\section{Harga $\left(\mathrm{X}_{1}\right)$}

Tabel II. Data Harga Sepatu Gino Mariani tahun 2011-2013 per Kuartal (dalam rupiah)

\begin{tabular}{|l|c|r|r|}
\hline TAHUN & KUARTAL & Realisasi HARGA (X1) & Target Harga \\
\hline 2011 & I & 204.700 & 210.000 \\
\hline & II & 204.800 & 215.000 \\
\hline & III & 215.200 & 220.000 \\
\hline 2012 & I & 219.500 & 225.000 \\
\hline & II & 228.600 & 230.000 \\
\hline & III & 230.900 & 235.000 \\
\hline 2013 & I & 232.200 & 250.000 \\
\hline & II & 261.100 & 280.000 \\
\hline & III & 291.700 & 310.000 \\
\hline
\end{tabular}

\section{Biaya Promosi $\left(\mathbf{X}_{2}\right)$}

Tabel III. Biaya Promosi tahun 2011 - 2013 Per Kuartal (dalam rupiah)

\begin{tabular}{|l|r|c|c|}
\hline \multirow{2}{*}{ Tahun } & KUARTAL & $\begin{array}{c}\text { Realisasi Promosi } \\
(\mathrm{X} 2)\end{array}$ & $\begin{array}{c}\text { Target } \\
\text { Promosi }\end{array}$ \\
\hline \multirow{4}{*}{2011} & $\mathrm{I}$ & 10.244 .000 & 12.000 .000 \\
\cline { 2 - 4 } & $\mathrm{II}$ & 15.366 .000 & 17.000 .000 \\
\cline { 2 - 4 } & III & 25.610 .000 & 26.000 .000 \\
\cline { 2 - 4 } 2012 & TOTAL & $\mathbf{5 1 . 2 2 0 . 0 0 0}$ & $\mathbf{5 5 . 0 0 0 . 0 0 0}$ \\
\cline { 2 - 4 } & I & 10.900 .000 & 12.000 .000 \\
\hline \multirow{4}{*}{2013} & II & 16.350 .000 & 20.000 .000 \\
\cline { 2 - 4 } & III & 27.250 .000 & 28.000 .000 \\
\cline { 2 - 4 } & TOTAL & $\mathbf{5 4 . 5 0 0 . 0 0 0}$ & $\mathbf{6 0 . 0 0 0 . 0 0 0}$ \\
\cline { 2 - 4 } & I & 10.350 .000 & 15.000 .000 \\
\cline { 2 - 4 } & III & 15.525 .000 & 20.000 .000 \\
\cline { 2 - 4 } & TOTAL & $\mathbf{5 1 . 7 5 0 . 0 0 0}$ & $\mathbf{6 5 . 0 0 0 . 0 0 0}$ \\
\hline
\end{tabular}


Pengaruh Penetapan Harga dan Biaya Promosi terhadap Hasil Penjualan Sepatu Gino Mariani pada PT. Sepatu Mas Idaman

Fauzan Zikri, Intan Pematasari, Zuber

\section{Pengaruh Harga sepatu Gino Mariani dan Biaya Promosi terhadap Hasil Penjualan}

Perhitungan pengaruh hubungan penetapan harga dan biaya promosi terhadap hasil penjualan akan dilakukan dengan menggunakan analisis regresi berganda. Seperti yang sudah dijelaskan pada bab sebelumnya, analisis regresi berganda untuk mengetahui apakah terdapat pengaruh dari variabel bebas $(\mathrm{X})$ terhadap variabel terkait $(\mathrm{Y})$. Pada PT. Sepatu Mas Idaman, terdapat dua variabel yang akan digunakan, yaitu variabel penetapan harga sepatu Gino Mariani $\left(\mathrm{X}_{1}\right)$ dan biaya promosi $\left(\mathrm{X}_{2}\right)$.

\section{Perhitungan Regresi Berganda}

Rumusnya adalah sebagai berikut:

$Y=a+b_{1} X_{1}+b_{2} X_{2}$

Persamaan $\mathrm{b}_{1}, \mathrm{~b}_{2}$, dan $\mathrm{a}$ :

1. $b_{1}=\frac{\left(\sum x_{2}^{2}\right) \cdot\left(\sum x_{1} \cdot y\right)-\left(\sum x_{1} x_{2}\right) \cdot\left(\sum x_{2} \cdot y\right)}{\left(\sum x_{1}^{2}\right) \cdot\left(\Sigma x_{2}^{2}\right)-\left(\sum x_{1} x_{2}\right) 2}$

$=\frac{(388084242) \cdot(984064925,9)-(633791,7) \cdot(28937384120,7)}{(6341,6) \cdot(388084242)-(633791,7)^{2}}$

$$
\begin{aligned}
& =\frac{198497361348719000}{12059365904142,6} \\
& b_{1}=96387,61 \\
& 2 \cdot b_{2}=\frac{\left(\sum x_{1}^{2}\right) \cdot\left(\sum x_{2} y\right)-\left(\sum x_{1} \cdot x_{2}\right) \cdot\left(\sum x_{1} y\right)}{\left(\sum x_{1}^{2}\right) \cdot\left(\sum x_{2}^{2}\right)-\left(\sum x_{1}, x_{2}\right) 2} \\
& =\frac{(6341,6) \cdot(28937384120,7)-(633791,7) \cdot(984064925,9)}{(6341,6) \cdot(88084242)-(633791,7)^{2}} \\
& =\frac{1211388141457690}{2059365904142,6} \\
& \mathrm{~b}_{2}=588,23 \\
& \text { 3. } \mathrm{a}=\frac{\Sigma Y}{n}-b_{1}\left[\frac{\sum X 1}{n}\right]-b_{2}\left[\frac{\sum X 2}{n}\right] \\
& \frac{120192017}{9}-(96387,61)\left[\frac{2090}{9}\right]-(58,23)\left[\frac{157470}{9}\right] \\
& \mathrm{a}=-19320803,41
\end{aligned}
$$

Setelah nilai $a, b_{1}$, dan $b_{2}$ diketahui, maka didapat persamaan regresi ganda sebagai berikut:

$Y=(19320803,41)+96387,61 X_{1}+588,23 X_{2}$

Menghitung nilai korelasi, yaitu : 
Pengaruh Penetapan Harga dan Biaya Promosi terhadap Hasil Penjualan Sepatu Gino Mariani pada PT. Sepatu Mas Idaman

Fauzan Zikri, Intan Pematasari, Zuber

1) Nilai regresi secara parsial antara Penetapan Harga $\left(X_{1}\right)$ terhadap Hasil Penjualan $(Y)$, bila Biaya Promosi $\left(\mathrm{X}_{2}\right)$ konstan.

$$
\begin{gathered}
\mathbf{r}_{\mathbf{x}_{1} \mathbf{y}}=\frac{\mathrm{n} \cdot \Sigma \mathrm{x}_{1} \mathrm{y}-\left(\Sigma \mathrm{x}_{1}\right)(\Sigma \mathrm{y})}{\sqrt{\mathrm{n} \cdot \Sigma \mathrm{x}_{1}^{2}-\left(\Sigma \mathrm{x}_{1}\right)^{2}} \sqrt{\mathrm{n} \cdot \Sigma \mathrm{y}^{2}-(\Sigma \mathrm{y})^{2}}} \\
=\frac{(9)(28895322206)-(2090)(120192017)}{\sqrt{(9)(491686)-(2090)^{2}} \sqrt{(9)(1885269962020070)-(120192017)^{2}}} \\
\mathbf{r}_{\mathrm{x}_{1} \mathbf{y}}=\frac{260057899854-251201315530}{\sqrt{57074} \cdot \sqrt{2521308707652370}} \\
r_{x_{1} . y}=\frac{8856584324}{238,90 \cdot 50212634,94} \\
r_{x_{1} . y}=\frac{8856584324}{11995881509} \\
r_{x_{1} y}=0,738
\end{gathered}
$$$$
r_{x_{1} \cdot y}=\frac{8856584324}{11995881509}
$$

Uji signifikansi t:

Ho $: \beta_{\mathrm{i} 2}=0$ : Tidak ada pengaruh Penetapan Harga terhadap Hasil Penjualan $\mathrm{Ha}: \beta_{\mathrm{j} 2}=0 /$ Ada pengaruh Penetapan Harga terhadap Hasil Penjualan

1) Menghitung nilai variasi regresi berganda $\left(S^{2} x_{1} \cdot x_{2}\right)$

$$
\begin{gathered}
S_{\mathrm{x}_{1} \times \mathrm{x} 2}^{2}=\frac{\Sigma \mathrm{y}^{2}-\left[b_{1}\left(\sum \mathrm{x}_{1} \mathrm{y}\right)+b_{2}\left(\mathrm{x}_{2} \mathrm{y}\right)\right.}{n-m-1} \\
S_{\mathrm{x}_{1} \times 2}=\frac{280145411961371-[96387,61(984064925,9)+588,23(28937384120,7)}{9-2-1} \\
=\frac{168271908207724}{9-2-1}=28045318034621
\end{gathered}
$$

2) Menghitung nilai standar deviasi regresi berganda $\left(S^{2} x_{1} \cdot x_{2}\right)$

$$
\begin{aligned}
& S^{2} \mathrm{x}_{1} \cdot \mathrm{x}_{2}=\sqrt{S^{2} x_{1} x_{2}} \\
& S^{2} \mathrm{x}_{1} \cdot \mathrm{x}_{2}=\sqrt{28045318034621} \\
& =5295783,04
\end{aligned}
$$

3) Menentukan nilai standar error $\left(\mathrm{S}_{\mathrm{b}}\right)$ 
Pengaruh Penetapan Harga dan Biaya Promosi terhadap Hasil Penjualan Sepatu Gino Mariani pada PT. Sepatu Mas Idaman

$$
\begin{gathered}
S_{b 1}=\frac{S x_{1} x_{2}}{\sqrt{\left[\Sigma \mathrm{x}_{1}^{2}-\mathrm{n} \cdot \overline{X_{1}^{2}}\right]}\left[1-\left(\begin{array}{lll}
r & \left.x_{1} x_{2}\right) & \left.{ }^{2}\right]
\end{array}\right.\right.} \\
S_{b 1}=\frac{5295783,04}{\sqrt{[491686-9 \cdot(53927,2)}]\left[1-(0,14){ }^{2}\right]} \\
S_{b 1}=\frac{5295783,04}{\sqrt{[124,28752}][0,02]} \\
=\frac{5295783,04}{11,15}=475024,95
\end{gathered}
$$

4) Menghitung nilai $t_{1 \text { hitung }}$

$$
\begin{aligned}
\mathrm{t}_{1 \text { hitung }}= & \underline{b i} \\
& S_{b i} \\
= & \underline{96387,61}=0,2029
\end{aligned}
$$$$
230,80
$$

$$
\begin{aligned}
& \mathrm{t}_{\text {tabel }}=\mathrm{t}(\alpha / 2)(\mathrm{n}-2) \\
& \mathrm{t}_{\text {tabel }}=\mathrm{t}(0,05 / 2)(9-2) \\
& \mathrm{t}_{\text {tabel }}=(0,025)(7)=2,3646
\end{aligned}
$$

$\mathrm{t}_{\text {hitung }}<\mathrm{t}_{\text {table }}$ atau 0,2029 $<2,3646$ maka $\mathrm{H}_{\mathrm{o}}$ diterima, artinya tidak ada hubungan yang signifikan antara penetapan harga terhadap penjualan.

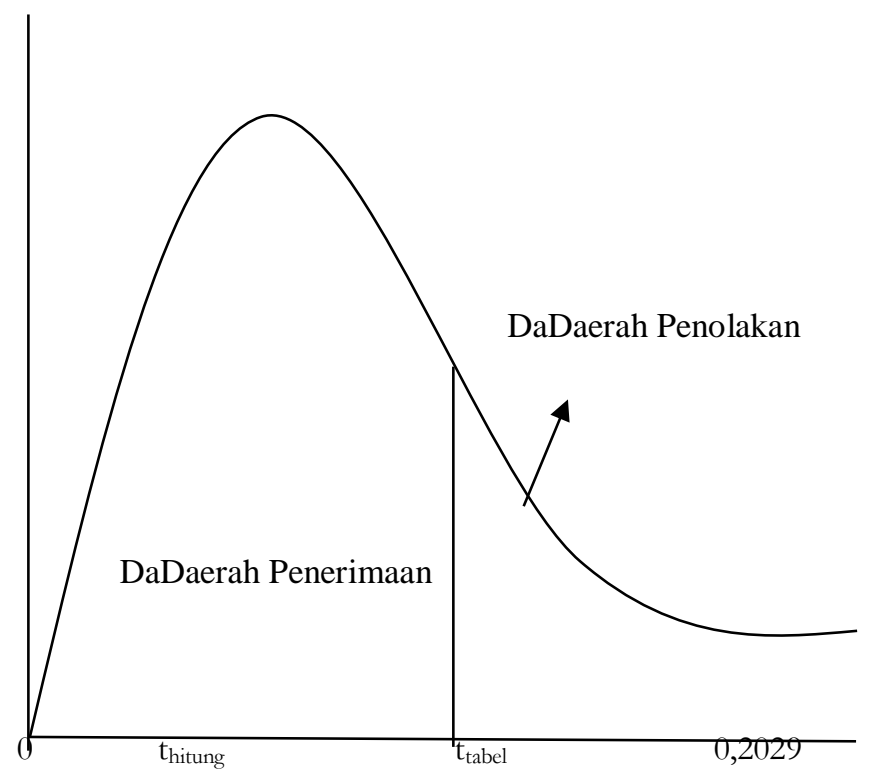


Pengaruh Penetapan Harga dan Biaya Promosi terhadap Hasil Penjualan Sepatu Gino Mariani pada PT. Sepatu Mas Idaman

2) Nilai regresi secara parsial antara Biaya Promosi $\left(\mathrm{X}_{2}\right)$ terhadap Hasil Penjualan $(\mathrm{Y})$, bila Penetapan Harga $\left(\mathrm{X}_{1}\right)$ konstan.

$$
\begin{gathered}
r_{x_{2} . y}=\frac{n\left(\sum X_{2} Y\right)-\left(\sum X_{2}\right)\left(\sum Y\right)}{\sqrt{\left(n \cdot \sum X_{2}{ }^{2}-\left(\sum X_{2}\right)^{2}\right) \cdot\left(n \cdot \sum Y^{2}-\left(\sum Y\right)^{2}\right)}} \\
r_{x_{2} . y}=\frac{9(2392333498646)-(157470)(120192017)}{\sqrt{(9)(3143284342)-(157470)^{2}} \sqrt{(9)(1885269962020070)-(120192017)^{2}}}
\end{gathered}
$$

$$
r_{x_{2} y}=\frac{2604364570824}{\sqrt{3492758178} \cdot \sqrt{2521308707652370}}
$$

$$
\begin{aligned}
& r_{x_{2} y}=\frac{2604364570824}{59099,56 \cdot 50212634,94} \\
& r_{x_{2} y}=\frac{2604364570824}{2967544710348,17} \\
& r_{x_{2} y}=0,878
\end{aligned}
$$

Uji signifikansi t:

Ho $: \beta_{\mathrm{j} 2}=0$ : Tidak ada pengaruh Biaya Promosi terhadap Hasil Penjualan

$\mathrm{Ha}: \beta_{\mathrm{j} 2} \neq 0$ : Ada pengaruh Biaya Promosi terhadap Hasil Penjualan

5) Menghitung nilai variasi regresi berganda $\left(S^{2} x_{1} \cdot x_{2}\right)$

$$
\begin{gathered}
S_{\mathrm{x}_{1} \times \mathrm{x} 2}^{2}=\frac{\Sigma \mathrm{y}^{2}-\left[b_{1}\left(\sum \mathrm{x}_{1} \mathrm{y}\right)+b_{2}\left(\mathrm{x}_{2} \mathrm{y}\right)\right.}{n-m-1} \\
S_{\mathrm{x}_{1} \times 22}=\frac{280145411961371-[96387,61(984064925,9)+588,23(28937384120,7)}{9-2-1} \\
=\frac{168271908207724}{9-2-1}=28045318034621
\end{gathered}
$$

6) Menghitung nilai standar deviasi regresi berganda $\left(\mathrm{S}^{2} \mathrm{x}_{1} \cdot \mathrm{x}_{2}\right)$

$$
\begin{aligned}
& S^{2} \mathrm{x}_{1} \cdot \mathrm{x}_{2}=\sqrt{S^{2} x_{1} x_{2}} \\
& S^{2} \mathrm{x}_{1} \cdot \mathrm{x}_{2}=\sqrt{28045318034621} \\
& =5295783,04
\end{aligned}
$$


Pengaruh Penetapan Harga dan Biaya Promosi terhadap Hasil Penjualan Sepatu Gino Mariani pada PT. Sepatu Mas Idaman

Fauzan Zikri, Intan Pematasari, Zuber

7) Menentukan nilai standar error $\left(\mathrm{S}_{\mathrm{bj}}\right)$

$$
\begin{gathered}
S_{b 1}=\frac{S x_{1} x_{2}}{\left.\sqrt{\left[\Sigma \mathrm{x}_{2}^{2}-\mathrm{n} \cdot \overline{X_{2}^{2}}\right.}\right]\left[1-\left(\mathrm{r} x_{1} x_{2}\right){ }^{2}\right]} \\
S_{b 1}=\frac{5295783,04}{\sqrt{[3143284342-9 \cdot(306133344)]\left[1-(0,14){ }^{2}\right]}} \\
S_{b 1}=\frac{5295783,04}{\sqrt{[124,28752][0,02]}} \\
=\frac{5295783,04}{2758}=1920,168
\end{gathered}
$$

8) Menghitung nilai $t_{1 \text { hitung }}$

$$
\begin{aligned}
& \mathrm{t}_{1 \text { hitung }}=\underline{b i} \\
& S_{b i} \\
& =\underline{588,23}=0,3063 \\
& 1920,168 \\
& \mathrm{t}_{\text {tabel }}=\mathrm{t}(\alpha / 2)(\mathrm{n}-2) \\
& \mathrm{t}_{\text {tabel }}=\mathrm{t}(0,05 / 2)(9-2) \\
& \mathrm{t}_{\text {tabel }}=(0,025)(7)=2,3646 \\
& \mathrm{t}_{\text {hitung }}<\mathrm{t}_{\text {table }} \text { atau } 0,3063<2,3 \\
& \text { signifikan antara penetapan hatg } \\
& \mathrm{t}_{\text {tabel }}=(0,025)(7)=2,3646 \\
& \mathrm{t}_{\text {tabel }}=\mathrm{t}(\alpha / 2)(\mathrm{n}-2) \\
& =\mathrm{t}(0,05 / 2)(9-2) \\
&
\end{aligned}
$$

$t_{\text {hitung }}<\mathrm{t}_{\text {table }}$ atau $0,3063<2,3646$ maka $\mathrm{H}_{\mathrm{o}}$ diterima, artinya tidak ada hubungan yang signifikan antara penetapan harga terhadap penjualan. 
Pengaruh Penetapan Harga dan Biaya Promosi terhadap Hasil Penjualan Sepatu Gino Mariani pada PT. Sepatu Mas Idaman

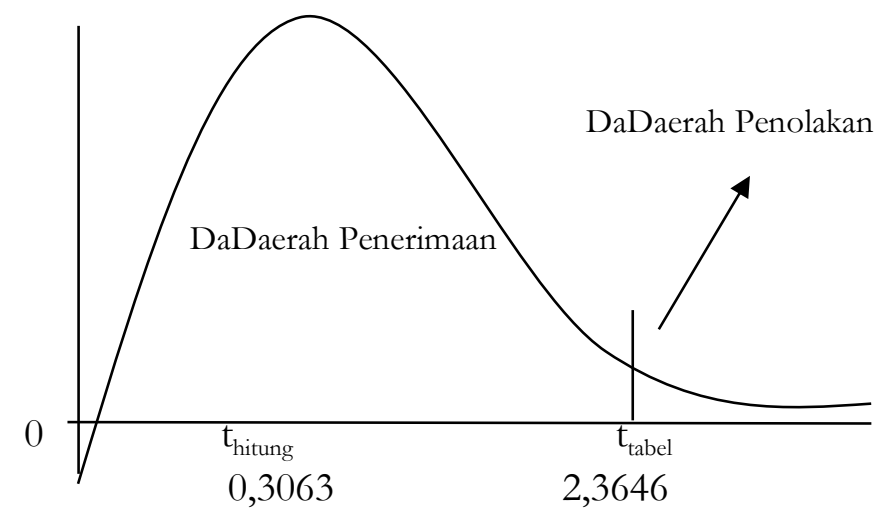

3) Nilai regresi secara parsial antara Penetapan Harga $\left(X_{1}\right)$ terhadap Biaya Promosi $\left(X_{2}\right)$.

$$
\begin{aligned}
& r_{x_{1} x_{2}}=\frac{n \cdot\left(\sum x_{1} x_{2}\right)-\left(\sum x_{1}\right)\left(\Sigma x_{2}\right)}{\sqrt{\left\{n \cdot \Sigma x_{1}^{2}-\left(\Sigma x_{1}\right)^{2}\right\}\left\{\sqrt{\left.n \cdot \Sigma x_{2}^{2}-\left(\sum x_{2}\right)^{2}\right\}}\right.}} \\
& r_{x_{1} x_{2}}=\frac{(9)(37201825)-(2090)(157470)}{\sqrt{\left[(9)(491686)-(2090)^{2}\right]\left[\sqrt{\left.(9)(3143284342)-(157470)^{2}\right]}\right.}} \\
& r_{x_{1} x_{2}}=\frac{334816425-(2090)(157470)}{\sqrt{(57074)(3492758178)}} \\
& r_{x_{1} x_{2}}=\frac{334816425-329112300}{\sqrt{1614598294817770}} \\
& r_{x_{1} x_{2}}=\frac{5704125}{40182064,34} \\
& r_{x_{1} x_{2}}=0,14
\end{aligned}
$$

4) Nilai korelasi secara simultan antara Penetapan Harga $\left(\mathrm{X}_{1}\right)$ dan Biaya Promosi $\left(\mathrm{X}_{2}\right)$ terhadap Hasil Penjualan (Y).

$$
\begin{array}{r}
R x_{1} \mathrm{x}_{2} \mathrm{y}=\sqrt{\frac{\mathrm{b} 1 . \Sigma x_{1} \mathrm{y}+\mathrm{b} 2 . \Sigma \mathrm{x}_{2} \mathrm{y}}{\Sigma \mathrm{y} 2}} \\
R x_{1} \mathrm{x}_{2} \mathrm{y}=\sqrt{\frac{11310,63.28895322206+627,23.2392333498646}{1885269962020070}}
\end{array}
$$




$$
\begin{gathered}
R x_{1} \mathrm{x}_{2} \mathrm{y}=\sqrt{\frac{1827367638558580}{1885269962020070}} \\
R x_{1} \mathrm{x}_{2} y=\sqrt{0,9693} \\
R x_{1} \mathrm{x}_{2} y=0,984
\end{gathered}
$$

Kontribusi yang diberikan secara simultan (bersama-sama) antara Penetapan Harga $\left(\mathrm{X}_{1}\right)$ dan Biaya Promosi $\left(\mathrm{X}_{2}\right)$ terhadap Hasil Penjualan $(\mathrm{Y})$.

$$
\begin{aligned}
\mathrm{KP} & =\left(R_{\mathrm{X} 1, \mathrm{X} 2 . \mathrm{Y}}\right)^{2} \times 100 \% \\
& =(0,984)^{2} \times 100 \% \\
& =96,8 \%
\end{aligned}
$$

Pengaruh penetapan harga sepatu Gino Mariani $\left(\mathrm{X}_{1}\right)$ dan biaya promosi $\left(\mathrm{X}_{2}\right)$ terhadap hasil penjualan tergolong sangat kuat. Sedang kontribusi (sumbangan secara langsung) variabel $\mathrm{X}_{1}$ dan $\mathrm{X}_{2}$ terhadap $(\mathrm{y})=\mathrm{R}^{2}$ × $100 \%$ atau $((0,968) \times 100 \%=96,8 \%)$ sedangkan, sisanya 3,2\% ditentukan oleh variabel lain disebabkan oleh faktor-faktor lainnya seperti dari produksi dan distribusi. Artinya, hubungan penetapan harga dan biaya promosi terhadap hasil penjualan kuat dan searah (mendekati 1) atau sangat mempengaruhi hasil penjualan.

Selanjutnya, untuk mengetahui signifikansi secara simultan antara $\mathrm{X}_{1}$ dan $\mathrm{X}_{2}$ terhadap Y dihitung dengan Uji F sebagai berikut:

- Penentuan Hipotesis

$\mathrm{H}_{0}=$ secara simultan tidak terdapat pengaruh penetapan harga dan biaya promosi

terhadap hasil penjualan; dan

$\mathrm{H}_{\mathrm{a}}=$ secara simultan terdapat pengaruh penetapan harga dan biaya promosi terhadap hasil penjualan.

- Penentuan level of significant

Level of significant ditentukan sebesar $5 \%$ atau $\alpha=0,05$

- Perhitungan $\mathrm{F}_{\text {tabel }}$ dan $\mathrm{F}_{\text {hitung }}$

$\mathrm{F}_{\text {tabel }}$ dapat diketahui dengan melihat tabel $\mathrm{f}$ yang disesuaikan dengan tingkat kesalahan yaitu sebesar 0,05

$$
\begin{aligned}
\mathrm{F}_{\text {tabel }} & =\mathrm{F}(1-\alpha)(\mathrm{dk}=\mathrm{k}),(\mathrm{dk}=\mathrm{n}-\mathrm{k}-1) \\
& =\mathrm{F}(1-0,05)(\mathrm{dk}=2),(\mathrm{dk}=9-2-1) \\
& =\mathrm{F}(1-0,05)(2,6) \\
& =5,14
\end{aligned}
$$


Pengaruh Penetapan Harga dan Biaya Promosi terhadap Hasil Penjualan Sepatu Gino Mariani pada PT. Sepatu Mas Idaman

Fauzan Zikri, Intan Pematasari, Zuber

Sedangkan $\mathrm{F}_{\text {hitung }}$ dapat diketahui dengan rumus sebagai berikut :

$F_{\text {hitung }}=\frac{\left(R x_{1}, \mathrm{x}_{2 .} y\right)^{2}(n-m-1)}{m\left(1-\mathrm{R}^{2}\right)}=\frac{(0,984)^{2}(9-2-1)}{2\left(1-(0,984)^{2}\right)}=\frac{5,809}{0,063}=92,206$

Kesimpulan :

$\mathrm{H}_{0}$ diterima apabila $\mathrm{F}_{\text {hitung }}<\mathrm{F}_{\text {tabel }}$ (Tidak Signifikan )

$\mathrm{H}_{\mathrm{a}}$ ditolak apabila $\mathrm{F}_{\text {hitung }}>\mathrm{F}_{\text {tabel }}($ Signifikan )

Keputusan :

Nilai $F_{\text {hitung }}=92,206$

Nilai $\mathrm{F}_{\text {Tabel }}=5,14$

Dengan demikian $\mathrm{H}_{0}$ ditolak, dan $\mathrm{H}_{\mathrm{a}}$ diterima, karena $\mathrm{F}_{\text {hitung }}<\mathrm{F}_{\text {tabel }}$ adalah 1,48 $<5,14$. Hal ini berarti terdapat pengaruh yang signifikan dari harga dan biaya promosi secara simultan (bersama-sama) terhadap hasil penjualan.

Kurva Uji F Pengaruh $X_{1}$ dan $X_{2}$ serta

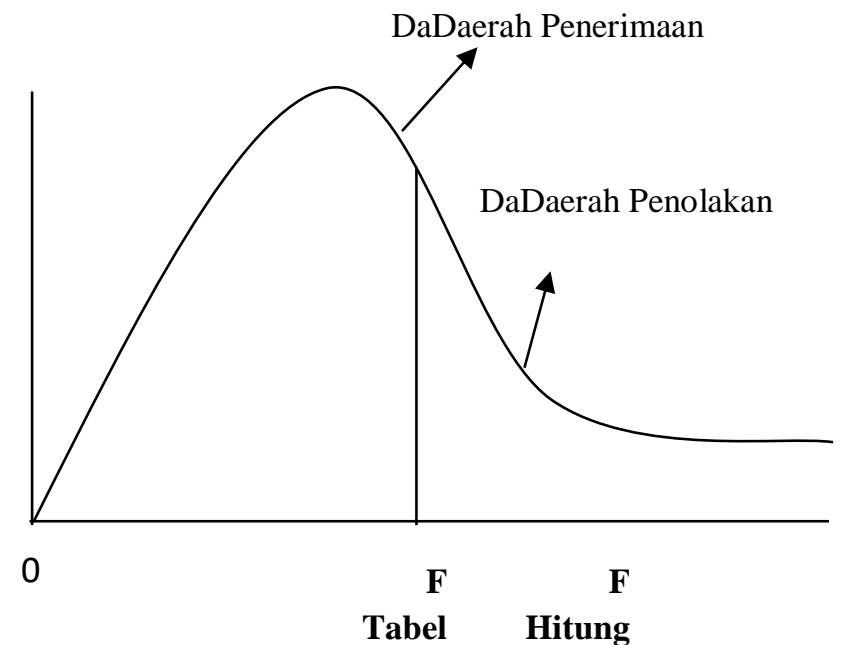

Pada pembahasan ini akan dilakukan analisis terhadap hasil perhitungan sebelumnya dengan menggunakan SPSS Versi 22.0.

\section{Analisis Hasil Uji Hipotesa}

Tabel IV. Tabel Correlations

\begin{tabular}{|c|c|c|c|c|}
\hline \multicolumn{5}{|c|}{ Correlations } \\
\hline & & $\begin{array}{l}\text { HASIL } \\
\text { PENTUALAN }\end{array}$ & HARGA & $\begin{array}{l}\text { BIAYA } \\
\text { PROMOSI }\end{array}$ \\
\hline \multirow[t]{3}{*}{ Pearson Correlation } & HASIL PENJUALAN & 1,000 &, 738 & ,878 \\
\hline & HARGA & .738 & 1,000 & ,404 \\
\hline & BIAYA PROMOSI & 878 & ,404 & 1,000 \\
\hline \multirow[t]{3}{*}{ Sig. (1-tailed) } & HASIL PENJUALAN & & ,012 & ,001 \\
\hline & HARGA & ,012 & & 140 \\
\hline & BIAYA PROMOSI &, 001 & , 140 & \\
\hline \multirow[t]{3}{*}{$\mathrm{N}$} & HASIL PENJUALAN & 9 & 9 & 9 \\
\hline & HARGA & 9 & 9 & 9 \\
\hline & BIAYA PROMOSI & 9 & 9 & 9 \\
\hline
\end{tabular}


Pengaruh Penetapan Harga dan Biaya Promosi terhadap Hasil Penjualan Sepatu Gino Mariani pada

Sumber: Pengolahan Data PT. Sepatu Mas Idaman, Perhitungan SPSS

Berdasarkan tabel IV. Hasil analisis korelasi parsial mengenai harga dan biaya promosi yang berpengaruh terhadap hasil penjualan, maka dapat di analisis sebagai berikut:

- Hasil perhitungan korelasi secara parsial antara variabel harga $\left(\mathrm{X}_{1}\right)$ dengan hasil penjualan $(\mathrm{Y})$ diperoleh nilai $\mathrm{r}=0,738$. Nilai ini menunjukkan korelasi positif sempurna dan kuat. Maksudnya positif sempurna dan kuat disini adalah terjadi hubungan yang searah antara harga $\left(\mathrm{X}_{1}\right)$ dan Hasil Penjualan $(\mathrm{Y})$. Jika, harga $\left(\mathrm{X}_{1}\right)$ naik maka hasil penjualan akan naik. Kontribusi yang disumbangkan variabel $\mathrm{X}_{1}$ terhadap $\mathrm{Y}$ adalah $\mathrm{KP}=(r)^{2} \mathrm{x} 100 \%=(0,738)^{2} \mathrm{x}$ $100 \%=54,46 \%$.

- Hasil perhitungan secara parsial antara variabel biaya promosi $\left(\mathrm{X}_{2}\right)$ dengan hasil penjualan $(\mathrm{Y})$ diperoleh nilai $\mathrm{r}=0,878$. Nilai ini menunjukkan korelasi positif sempurna dan kuat. Maksudnya positif sempurna dan kuat disini adalah terjadi hubungan yang searah antara biaya promosi $\left(\mathrm{X}_{2}\right)$ dan Hasil Penjualan $(\mathrm{Y})$. Jika biaya promosi naik maka tingkat penjualan akan naik. Kontribusi yang disumbangkan variabel $\mathrm{X}_{2}$ terhadap $\mathrm{Y}$ adalah $\mathrm{KP}=(r)^{2} \times 100 \%=$ $(0,878)^{2} \times 100 \%=77,09 \%$.

Tabel V. Model Summary

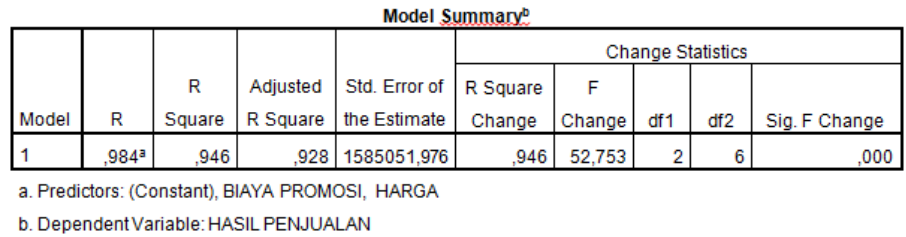

Sumber: Pengolahan Data PT. Sepatu Mas Idaman, Perhitungan SPSS

Berdasarkan tabel V. Model Summary hasil analisis korelasi $(\mathrm{R})$ yang secara simultan (bersamasama) antara variabel harga $\left(\mathrm{X}_{1}\right)$ dan biaya promosi $\left(\mathrm{X}_{2}\right)$ terhadap hasil penjualan $(\mathrm{Y})$ diperoleh nilai sebesar $\mathrm{R}=0,984$. Menunjukkan secara simultan variabel penetapan harga dan biaya promosi yang hubungannya positif sempurna dan sangat kuat terhadap hasil penjualan yang artinya searah antara $\mathrm{X}$ dan $\mathrm{Y}$, jika $\mathrm{X}_{1}$ dan $\mathrm{X}_{2}$ naik maka $\mathrm{Y}$ akan naik. Sementara yang disumbangkan secara simultan oleh variabel $\mathrm{X}_{1}$ dam $\mathrm{X}_{2}$ terhadap $\mathrm{Y}$ adalah: $\quad \mathrm{KP}=\left(\mathrm{R}_{\mathrm{X} 1}\right.$, $\mathrm{x} 2 . \mathrm{Y})^{2} \times 100 \%=(0,984)^{2} \times 100 \%=96,8 \%$, sedangkan, sisanya $3,2 \%$ ditentukan oleh variabel lain disebabkan oleh faktor-faktor lainnya seperti dari produksi dan distribusi. 
Pengaruh Penetapan Harga dan Biaya Promosi terhadap Hasil Penjualan Sepatu Gino Mariani pada PT. Sepatu Mas Idaman

Fauzan Zikri, Intan Pematasari, Zuber

\section{Pengujian Hipotesa}

Tabel VI. ANOVA ${ }^{a}$

\begin{tabular}{|ll|r|c|c|c|c|}
\hline Model & & Sum of Squares & df & Mean Square & F & Sig. \\
\hline 1 & Regression & 26507107336737 & 2 & 13253553668368 & & \\
& & 3,220 & 2 & 6,610 & 92,206 &, $000^{\circ}$ \\
& Residual & 15074338594001 & 6 & 2512389765666, & & \\
& & 014 & 6 & 835 & & \\
& Total & 28014541196137 & & & & \\
& & 4,220 & 8 & & & \\
\hline
\end{tabular}

a. Dependent Variable: HASIL PENJUALAN

b. Predictors: (Constant), BIAYA PROMOSI, HARGA

Sumber: Pengolahan Data PT. Sepatu Mas Idaman, Perhitungan SPSS

Berdasarkan tabel VI. ANOVA Kriteria keputusan yang diambil sebagai berikut:

Perbandingan $\mathrm{F}_{\text {hitung }}$ dan $\mathrm{F}_{\text {tabel }}$

Jika: $\mathrm{F}_{\text {hitung }}<\mathrm{F}_{\text {tabel }}$, maka $\mathrm{H}_{0}$ diterima

Jika: $\mathrm{F}_{\text {hitung }}>\mathrm{F}_{\text {tabel }}$, maka $\mathrm{H}_{0}$ ditolak

Nilai $F_{\text {hitung }}$ tabel ANOVA sebesar $=92,206$

Nilai $\mathrm{F}_{\text {Tabel }}$ dari tabel $\mathrm{F}=5,14$

Membandingkan $\mathrm{F}_{\text {tabel }}$ dan $\mathrm{F}_{\text {hitung }}$

Ternyata: $\mathrm{F}_{\text {Hitung }}=92,206>\mathrm{F}_{\text {tabel }}=5,14$ berarti $\mathrm{H}_{0}$ ditolak dan terdapat pengaruh yang signifikan secara simultan antara harga $\left(\mathrm{X}_{1}\right)$ dan biaya promosi $\left(\mathrm{X}_{2}\right)$ terhadap hasil penjualan (Y).

Tabel VII. Coefficientsa

\begin{tabular}{|c|c|c|c|c|c|c|}
\hline \multicolumn{7}{|c|}{ Coefficients $\mathrm{s}^{\mathrm{a}}$} \\
\hline \multirow[b]{2}{*}{ Mode } & & \multicolumn{2}{|c|}{ Unstandardized Coefficients } & \multirow{2}{*}{$\begin{array}{c}\begin{array}{c}\text { Standardized } \\
\text { Coefficients }\end{array} \\
\text { Beta } \\
\end{array}$} & \multirow[b]{2}{*}{ t } & \multirow[b]{2}{*}{ Sig. } \\
\hline & & B & Std. Error & & & \\
\hline 1 & (Constant) & $\mid-19320803,412$ & 4679358,154 & & $-4,129$ &, 006 \\
\hline & HARGA & 96387,612 & 21759,041 &, 459 & 0,2029 &, 040 \\
\hline & BIAYA PROMOSI & 588,234 & 87,958 & ,692 & 0,3063 &, 030 \\
\hline
\end{tabular}

a. DependentVariable: HASIL PENJUALAN

Sumber: Pengolahan Data PT. Sepatu Mas Idaman, Perhitungan SPSS 
Pengaruh Penetapan Harga dan Biaya Promosi terhadap Hasil Penjualan Sepatu Gino Mariani pada PT. Sepatu Mas Idaman

Fauzan Zikri, Intan Pematasari, Zuber

Berdasarkan tabel V.19 hasil analisis regresi berganda mengenai penetapan harga dan biaya promosi yang berpengaruh terhadap hasil penjualan, maka dapat di tulis persamaan regresi yakni sebagai berikut:

$$
Y=(19320803,412)+96387,612 X_{1}+588,234 X_{2}
$$

Dari hasil perhitungan tersebut dapat diartikan sebagai berikut :

- Nilai $\mathrm{b}_{0}=-19320803,412$ artinya jika penetapan harga $\left(\mathrm{X}_{1}\right)$ dan biaya promosi $\left(\mathrm{X}_{2}\right)$ sama dengan nol, maka penjualan (Y) akan sebesar Rp. 19.320.803.412

- $\quad$ Nilai $\mathrm{b}_{1}=96387,612$ artinya jika biaya promosi $\left(\mathrm{X}_{2}\right)$ konstan apabila penetapan harga $\left(\mathrm{X}_{1}\right)$ naik sebesar Rp. 1.000 Maka pengaruh atas hasil penjualan (Y) sepatu Gino Mariani akan meningkat sebesar Rp 96.387 .612

- Nilai $\mathrm{b}_{2}=588,234$ artinya jika penetapan harga $\left(\mathrm{X}_{1}\right)$ konstan apabila biaya promosi $\left(\mathrm{X}_{2}\right)$ naik sebesar Rp. 1.000 maka pengaruhnya atas penjualan $(\mathrm{Y})$ akan meningkat sebesar Rp. 588.234

Uji t

Berdasarkan tabel V.19 coefficients kriteria keputusan yang diambil adalah sebagai berikut:

a. Penetapan Harga $\left(\mathrm{X}_{1}\right)$

Jika : $\mathrm{t}_{\text {hitung }}<\mathrm{t}_{\text {tabel }}$, maka $\mathrm{H}_{0}$ diterima

Jika : $\mathrm{t}_{\text {hitung }}>\mathrm{t}_{\text {tabel }}$, maka $\mathrm{H}_{0}$ ditolak

- Nilai $t_{\text {hitung }}$ pada tabel coefficient sebesar 0,2029

Nilai $\mathrm{t}_{\text {tabel }} \mathrm{t}=2,3646$

- Membandingkan $\mathrm{t}_{\text {tabel }}$ dan $\mathrm{t}_{\text {hitung }}$ Penetapan Harga $\left(\mathrm{X}_{1}\right)$ :

Ternyata $\mathrm{t}_{\text {hitung }} 0,2029<\mathrm{t}_{\text {tabel }}$ 2,3646 berarti $\mathrm{H}_{0}$ diterima dan tidak terdapat pengaruh secara parsial antara Penetapan Harga $\left(\mathrm{X}_{1}\right)$ dan Hasil Penjualan $(\mathrm{Y})$.

b. Biaya Promosi $\left(\mathrm{X}_{2}\right)$

Jika : $\mathrm{t}_{\text {hitung }}<\mathrm{t}_{\text {tabel }}$, maka $\mathrm{H}_{0}$ diterima

Jika : $\mathrm{t}_{\text {hitung }}>\mathrm{t}_{\text {tabel }}$, maka $\mathrm{H}_{0}$ ditolak

- Nilai $t_{\text {hitung }}$ pada tabel coefficient sebesar 0,3063

Nilai $\mathrm{t}_{\text {tabel }} \mathrm{t}=2,3646$

- Membandingkan $t_{\text {tabel }}$ dan $t_{\text {hitung }}$ Biaya Promosi $\left(\mathrm{X}_{2}\right)$ :

Ternyata $\mathrm{t}_{\text {hitung }} 0,3063<\mathrm{t}_{\text {tabel }} 2,3646$ berarti $\mathrm{H}_{0}$ diterima dan tidak terdapat pengaruh secara parsial antara Biaya Promosi $\left(\mathrm{X}_{2}\right)$ dan Hasil Penjualan (Y).

c. Kriteria Keputusan yang diambil berdasarkan probabilitas :

1. Penetapan Harga $\left(\mathrm{X}_{1}\right)$

Jika Probabilitas (sig) $>(\alpha / 2)$, maka $\mathrm{H}_{0}$ diterima ; dan

Jika Probabilitas $(\mathrm{sig})<(\alpha / 2)$, maka $\mathrm{H}_{0}$ ditolak 
Pengaruh Penetapan Harga dan Biaya Promosi terhadap Hasil Penjualan Sepatu Gino Mariani pada PT. Sepatu Mas Idaman

Dari tabel coefficient berdasarkan nilai probabilitas (sig) $=0,040$ dan nilai taraf signifikan $\alpha$ $=0,025$, hasil perbandingannya adalah ternyata $0,040>0,025$, maka $\mathrm{H}_{0}$ diterima dan tidak terdapat pengaruh yang signifikan secara parsial antara Penetapan Harga $\left(X_{1}\right)$ dengan Hasil Penjualan (Y).

2. Biaya Promosi $\left(\mathrm{X}_{2}\right)$

Jika Probabilitas (sig) $>(\alpha / 2)$, maka $\mathrm{H}_{0}$ diterima ; dan

Jika Probabilitas $($ sig $)<(\alpha / 2)$, maka $\mathrm{H}_{0}$ ditolak

Dari tabel coefficient berdasarkan nilai probabilitas (sig) $=0,030$ dan nilai taraf signifikan $\alpha$ $=0,025$, hasil perbandingannya adalah ternyata $0,030>0,025$, maka $\mathrm{H}_{0}$ diterima dan tidak terdapat pengaruh yang sangat signifikan secara parsial antara Biaya Promosi $\left(\mathrm{X}_{2}\right)$ dengan Hasil Penjualan (Y).

\section{KESIMPULAN}

Dari hasil pembahasan mengenai pengaruh penetapan harga dan biaya promosi terhadap Hasil Penjualan dari tahun 2016-2018, maka dapat disajikan kesimpulan sebagai berikut:

1. Berdasarkan pengujian hipotesis secara simultan dan parsial diperoleh :

a. Hasil Analisis Regresi ganda maka diperoleh persamaan :

$\hat{Y}=(19320803,412)+96387,612 X_{1}+588,234 X_{2}$

Dimana:

- Nilai $\mathrm{b}_{0}=-19320803,412$ artinya jika penetapan harga $\left(\mathrm{X}_{1}\right)$ dan biaya promosi $\left(\mathrm{X}_{2}\right)$ sama dengan nol, maka penjualan (Y) akan sebesar Rp. 19.320.803.412

- Nilai $b_{1}=96387,612$ artinya jika biaya promosi $\left(\mathrm{X}_{2}\right)$ konstan apabila penetapan harga $\left(\mathrm{X}_{1}\right)$ naik sebesar Rp. 1.000 Maka pengaruh atas hasil penjualan $(\mathrm{Y})$ sepatu Gino Mariani akan meningkat sebesar Rp 96.387 .612

- Nilai $\mathrm{b}_{2}=588,234$ artinya jika penetapan harga $\left(\mathrm{X}_{1}\right)$ konstan apabila biaya promosi $\left(\mathrm{X}_{2}\right)$ naik sebesar Rp. 1.000 maka pengaruhnya atas penjualan (Y) akan meningkat sebesar Rp. 588.234

b. $F_{\text {Hitung }}=92,206>F_{\text {tabel }}=5,14$ berarti $\mathrm{H}_{0}$ ditolak dan terdapat pengaruh yang signifikan secara simultan antara harga $\left(\mathrm{X}_{1}\right)$ dan biaya promosi $\left(\mathrm{X}_{2}\right)$ terhadap hasil penjualan $(\mathrm{Y})$.

c. $\mathrm{t}_{\text {hitung }} 2,896>\mathrm{t}_{\text {tabel }}$ 2,3646 berarti $\mathrm{H}_{0}$ ditolak dan terdapat pengaruh positif secara parsial antara Penetapan Harga $\left(\mathrm{X}_{1}\right)$ dan Hasil Penjualan $(\mathrm{Y})$.

d. $t_{\text {hitung }} 4,860>t_{\text {tabel }} 2,3646$ berarti $\mathrm{H}_{0}$ ditolak dan terdapat pengaruh positif secara parsial antara Biaya Promosi $\left(\mathrm{X}_{2}\right)$ dan Hasil Penjualan (Y). 
Pengaruh Penetapan Harga dan Biaya Promosi terhadap Hasil Penjualan Sepatu Gino Mariani pada PT. Sepatu Mas Idaman

Fauzan Zikri, Intan Pematasari, Zuber

Berdasarkan perhitungan koefisien determinasi $\operatorname{Rx}_{1} \mathrm{x}_{2}, \mathrm{y}=0,984$ menunjukkan secara simultan variabel penetapan harga dan biaya promosi yang hubungannya positif sempurna dan sangat kuat terhadap hasil penjualan dimana perhitungan korelasi mendekati 1. Sementara yang disumbangkan secara simultan oleh variabel $\mathrm{X}_{1}$ dam $\mathrm{X}_{2}$ terhadap $\mathrm{Y}$ adalah: $\mathrm{KP}=\left(R_{\mathrm{X} 1, \mathrm{x} 2 \mathrm{Y}}\right)^{2} \mathrm{x}$ $100 \%=(0,984)^{2} \times 100 \%=96,8 \%$, sedangkan, sisanya 3,2 \% ditentukan oleh variabel lain disebabkan oleh faktor-faktor lainnya seperti dari produksi dan distribusi.

2. Hasil perhitungan korelasi secara parsial antara variabel Penetapan Harga $\left(X_{1}\right)$ dengan Hasil Penjualan $(Y)$ diperoleh nilai $r=0,738$. Dengan tingkat kontribusi yang disumbangkan variabel $\mathrm{X}_{1}$ terhadap $\mathrm{Y}$ adalah $\mathrm{KP}=(r)^{2} \times 100 \%=(0,738)^{2} \times 100 \%=54,46 \%$ dan variabel $\mathrm{X}_{2}$ dianggap konstan, apabila sisa sebesar $45,54 \%$ dipengaruhi oleh variabel lain. Hasil perhitungan korelasi secara parsial antara variabel Biaya Promosi $\left(\mathrm{X}_{2}\right)$ dengan Hasil Penjualan $(Y)$ diperoleh nilai $r=0,878$. Dengan tingkat kontribusi yang disumbangkan variabel $\mathrm{X}_{2}$ terhadap $\mathrm{Y}$ adalah $\mathrm{KP}=(r)^{2} \times 100 \%=(0,878)^{2} \times 100 \%=77,09 \%$ dan variabel $\mathrm{X}_{1}$ dianggap konstan, apabila sisa sebesar 22,91\% dipengaruhi oleh variabel lain. Berdasarkan data di atas maka dapat diketahui bahwa variabel yang memiliki kontribusi paling tinggi adalah Biaya Promosi $\left(\mathrm{X}_{2}\right)$.

\section{DAFTAR PUSTAKA}

Assauri, Sofjan. Manajemen Pemasaran. Ed. 1-8. Jakarta: PT. Raja Grafindo Persada, 2007.

Abdullah, T., \& Tantri, P. (2013). Manajemen pemasaran. Jakarta: PT. Raja Grafindo Persada.

Batubara, A., \& Rahmat, H. (2016). Pengaruh Penetapan Harga dan Promosi terhadap Tingkat Penjualan Tiket pada PSA Mihin Lanka Airlines. Jurnal IIman, Vol. 4, No. 1, pp. 33-46.

Dharasta, You, S.M.A. (2017). Pengaruh Penetapan Harga dan Promosi terhadap Tingkat Penjualan Tikey (Studi Kasus pada Jasa Travel Agent di Wilayah Yogyakarta). Jurnal Manajemen Dingantara Vol.10 No.2

Eva Z. Yusuf, Lesley Williams. Manajemen Pemasaran: Studi Kasus Indonesia; Penerjemah: Abdul Rosyid; Editor Y. Yuwono-Jakarta: Penerbit PPM, 2007.

Herlambang, S. (2014). Basic Marketing, Cara Mudah Memahami Ilmu Pemasaran. Yogyakarta: Gosyen Publishing.

Kotler, P. \& Keller, K. L. (2012). Marketing Management (14th ed.). United States of America: Pearson

Machfoedz, M. (2010). Komunikasi Pemasaran Modern (1th ed.). Yogyakarta: Cakra Ilmu. 
Pengaruh Penetapan Harga dan Biaya Promosi terhadap Hasil Penjualan Sepatu Gino Mariani pada PT. Sepatu Mas Idaman

Fauzan Zikri, Intan Pematasari, Zuber

Rangkuti, Fredy. Riset Pemasaran. Cetakan kesebelas: November 2013. Jakarta: Penerbit PT. Gramedia Pustaka Utama, 1997.

Sugiono. Metode Penelitian Bisnis. CV. Alfabeta: Bandung, 2004

Siregar, Sofyan. Statistik Parametrik untuk Penelitian Kuantitatif: dilengkapi dengan Perbitungan SPSS Versi 17; editor, Fandy Hutari. -Ed.1, Cet.2. - Jakarta: Bumi Aksara, 2014.

Suharno \& Sutarso, Y. (2010). Marketing in Practice. Yogyakarta: Graha Ilmu.

Sumarwan, U., Puspitawati, H., Hariadi, A., Ali, M. M., Gazali, M., Hartono, S., \& Farina, T. (2013). Riset Pemasaran dan Konsumen. Bogor: PT. Penerbit IPB Press.

Sunyoto, D. (2013). Teori, Kuisioner, dan Analisis Data. Yogyakarta: Graha Ilmu.

Tjiptono, F \& Chandra, G. (2012). Pemasaran Strategik (2th ed.). Yogyakarta: Andi.

Yet, S. (2011). Start Marketing. Jakarta: PT. Gramedia Pustaka Utama. 